\title{
In this together: China-EU relations in the COVID-19 era
}

\section{Huiyao Wang ${ }^{1} \cdot$ Lu Miao $^{1}$}

Published online: 30 May 2020

C) Springer-Verlag GmbH Germany, part of Springer Nature 2020

2020 was set to be a major year for China-EU diplomacy. The regular EU-China summit at the end of March was a chance for China to strengthen ties with the new EU leadership that took over last summer, reaffirm commitments, and seek new areas for cooperation. This was to be immediately followed by the annual 17+1 meeting in April and later the newly created EU27-China leader's meeting in September, with a new format involving President $\mathrm{Xi}$ and all 27 leaders of EU member states.

Suddenly, the COVID-19 outbreak hit.

In just a few months, the pandemic has turned our world upside down, claiming hundreds of thousands of lives and affecting every country on earth.

Amidst the crisis, deep ties between China and the EU have been shown through mutual assistance. In January, as China bore the brunt of the initial outbreak, EU governments, companies, and civil society provided support to China. Later, as the pandemic epicenter shifted westwards, this was reciprocated as China sent PPE and doctors to Europe.

But inevitably, there has been significant disruption. Trade and supply chains linking China and Europe have been hit, movement between the two regions curtailed, and the China-EU summit and 17+1 called off. Tensions across the Pacific and Atlantic have also affected the global context of China-EU relations.

More than anything else, the crisis has shown how deeply entwined the fates of China, Europe, and indeed the whole world are. Despite the current geopolitical flux and talk of great power competition, shared interests between China and the EU run deep. At a time when international cooperation is needed, pragmatic joint efforts by the two sides could be pivotal to spurring global pandemic control and recovery.

The article starts by mapping out current challenges posed by COVID-19 regarding public health, economy, and politics. This is followed by a discussion of the need for

Huiyao Wang

wanghuiyao@ccg.org.cn

Lu Miao

miaolv@ccg.org.cn

1 Center for China and Globalization, Beijing, China 
China-EU cooperation to galvanize global recovery from the pandemic, and finally, promising areas for both sides to work together.

\section{The shared challenges of COVID-19}

China and Europe were among the first regions to be hit by COVID-19. While the trajectory of the pandemic and its economic fallout remain unclear, we can outline three main themes that China and the EU will have to address.

First and foremost, the tragic cost to human life has been great and is far from over. While the situation has been stabilized in some regions, there is a continued risk of reinfections from abroad and second or third waves as lockdown measures are loosened. How long this will last remains unclear, but until a vaccine is found, no country can be safe until all countries are safe. Cooperation for medical supplies and virus research will be critical. At the same time, travel restrictions will affect the movement of people between China and the EU, as between all regions, impacting key linkages such as business, tourism, and overseas study. In the meantime, contingency measures such as remote interaction will help to fill the gap.

Economic fallout will be prolonged, from production and consumption to knock-on effects on financial and commodity markets. As China gets back to work, trade with the EU is recovering. European auto manufacturers such as Daimler report that business in China has stabilized in March as the nation emerges from lockdown. But given the difficulty of balancing containment and reviving the economy, the recovery will be gradual and uneven, with certain countries and industries particularly afflicted.

Looking to the longer term, the pandemic will also shape the broader global context of China-EU relations. In many ways, this may work to reinforce, rather than fundamentally alter, broader trends that were clear before the pandemic hit.

Social and economic pressures will impact politics, both within states and between them. Politicians under fire for their pandemic response may seek to blame other countries. We have already seen how anxiety and precarity can exacerbate xenophobia, populism, and anti-globalization sentiment. The stresses of dealing with the pandemic can amplify tensions such as between China and the USA and between northern and southern EU countries over corona bonds. These factors will also play into China-EU relations.

\section{China-EU cooperation in a multipolar world}

The challenges outlined above put strain on international cooperation at a time when it is needed most. Despite efforts by the WHO and G20, overall, the pandemic has shown that our global institutions have not kept up with the challenges of our twenty-firstcentury global reality.

But even more so, the pandemic has shown how interdependent our global village is. Unless we want to live in hermetically sealed isolation, no country can be safe until all countries are safe. For China and the EU, which share deep economic linkages and 
support for an open, multilateral order, the imperative to work together is even stronger. Our roads to recovery run side by side.

The world is increasingly multipolar, and divergent recovery trajectories out of the pandemic are likely to reinforce this trend. In this context, no country alone can address the transnational challenges we face. This is especially true for a virus that knows no borders but also goes for other threats like climate change and inequality.

In this multipolar context, the world's three largest economies and most influential global players - China, the EU, and the USA - remain the best placed to galvanize cooperation. But at a time when US commitment to international cooperation is in doubt under the current administration, the onus falls on China and the EU to adopt a pragmatic approach and work together.

\section{Areas for China-EU cooperation}

As the China-EU relationship has become deeper and more multifaceted, it is inevitable there will be aspects of competition and differences between the two sides at times. However, in the big picture, our shared interests still more than outweigh these differences.

Amidst a climate of intensifying political rhetoric, it is important for China and the EU to retain a pragmatic approach and cultivate shared interests and synergies that can benefit not only both sides but the whole world. Promising areas for cooperation that stand out include re-invigorating multilateralism, economic cooperation, sustainability, and third-country cooperation.

With multilateralism under strain, China-EU cooperation could be pivotal in providing the momentum to forge consensus, strengthen global governance, and develop joint solutions to our shared challenges.

For example, both sides are working to enhance the role of the WHO to coordinate global public health measures. Another priority is re-invigorating the WTO. During the current crisis, more than 60 governments have imposed export restrictions on medical equipment and essential drugs for treating COVID-19 symptoms. Many have also placed limits on the export of food products.

This kind of protectionism can exacerbate supply shortages and is a particular threat to less-developed countries. In the short term, China and the EU could work together to help re-tool the WTO to address this issue and smooth essential trade flows. In the longer term, reviving the WTO is important to support free trade and global economic recovery.

Economic cooperation has been the bedrock of China-EU ties and remains a top item on this year's bilateral agenda. There are many untapped economic opportunities between China and the EU, and these will continue to grow with China's economic transformation and the growing spending power of its consumers. Daily two-way trade was estimated to exceed $\$ 1.6$ billion daily before the pandemic struck. Joint efforts can help restore and rebuild supply chains linking China and the EU that create mutual benefits and support the global economic recovery.

Bilateral investment is also important. Both sides aim to conclude the Comprehensive Agreement on Investment this year, and EU president Ursula von der Leyen has committed to proactively proceed with negotiations that have been delayed due to the 
current disruption. Securing this deal would open opportunities for Chinese and European businesses and represent a major win for China-EU relations.

Sustainability can be another bright spot for cooperation. At a time when the White House has turned away from green issues and the Paris Climate Change Agreement, it is all the more important that China and the EU lead in helping the world transition to a clean future. While COVID-19 has overshadowed the climate crisis, in the long term, it remains one of the world's most pressing challenges. It is also linked to the risk of future pandemics, given factors such as the impact of environmental change on zoonotic transmission to humans.

Finally, there is much scope for China-EU cooperation in third countries, both for pandemic response in vulnerable regions and long-term development. Africa, for example, is a place where both sides can offer complementary strengths that can benefit both sides as well as local communities. Indeed, development cooperation was reported to be a key agenda item for the Leipzig summit in September.

The current pandemic has disrupted plans for China-EU engagement this year, and will generate new challenges to navigate in the short to medium term. But that should not obscure the fact that both sides have a great deal of shared interest and that joint efforts can be crucial for the global recovery from the current crisis.

Previous times of suffering and upheaval have opened windows to reimagine international cooperation, such as the rebuilding of global institutions and multilateralism after World War II. If this dark COVID cloud has a silver lining, it may be to force us to re-think our global approach and the need to work together to build a more inclusive, resilient multilateral order for the twenty-first century. If they can work together, China and the EU have a great opportunity to spearhead that change. 